University of Nebraska - Lincoln

DigitalCommons@University of Nebraska - Lincoln

Faculty Publications: Department of Teaching, Department of Teaching, Learning and Teacher Learning and Teacher Education

Education

September 2002

\title{
Expecting, Accepting, and Respecting Difference in Middle School
}

Lori Olafson

University of Nevada, Las Vegas, Iolafson@ccmail.nevada.edu

Margaret A. Macintyre Latta

University of Nebraska-Lincoln, Margaret.Macintyre.Latta@ubc.ca

Follow this and additional works at: https://digitalcommons.unl.edu/teachlearnfacpub

Part of the Teacher Education and Professional Development Commons

Olafson, Lori and Macintyre Latta, Margaret A., "Expecting, Accepting, and Respecting Difference in Middle School" (2002). Faculty Publications: Department of Teaching, Learning and Teacher Education. 24. https://digitalcommons.unl.edu/teachlearnfacpub/24

This Article is brought to you for free and open access by the Department of Teaching, Learning and Teacher Education at DigitalCommons@University of Nebraska - Lincoln. It has been accepted for inclusion in Faculty Publications: Department of Teaching, Learning and Teacher Education by an authorized administrator of DigitalCommons@University of Nebraska - Lincoln. 


\section{Expecting, Accepting, and Respecting Difference in Middle School}

The curriculum need not fight young adolescents' need to engage in identity formation. It can assist that process when students are given the opportunity to address issues that matter to them through their school work.

By Lori Olafson \& Margaret Macintyre Latta

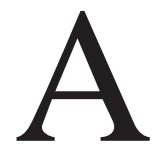
dolescence is a time when key questions of identity assume central importance in the lives of children (Brumberg, 1997).

It is often a particularly traumatic time for girls as they negotiate through the quagmire of adolescent experience (Harper, 1997). During the time we spent researching and teaching in middle schools, we found that the voices of adolescent girls echoed this fragile and vulnerable sense of self.

We were engaged in separate interpretive research studies in middle schools that allowed the depth and complexity of participants' learning experiences to be explored. We approached the

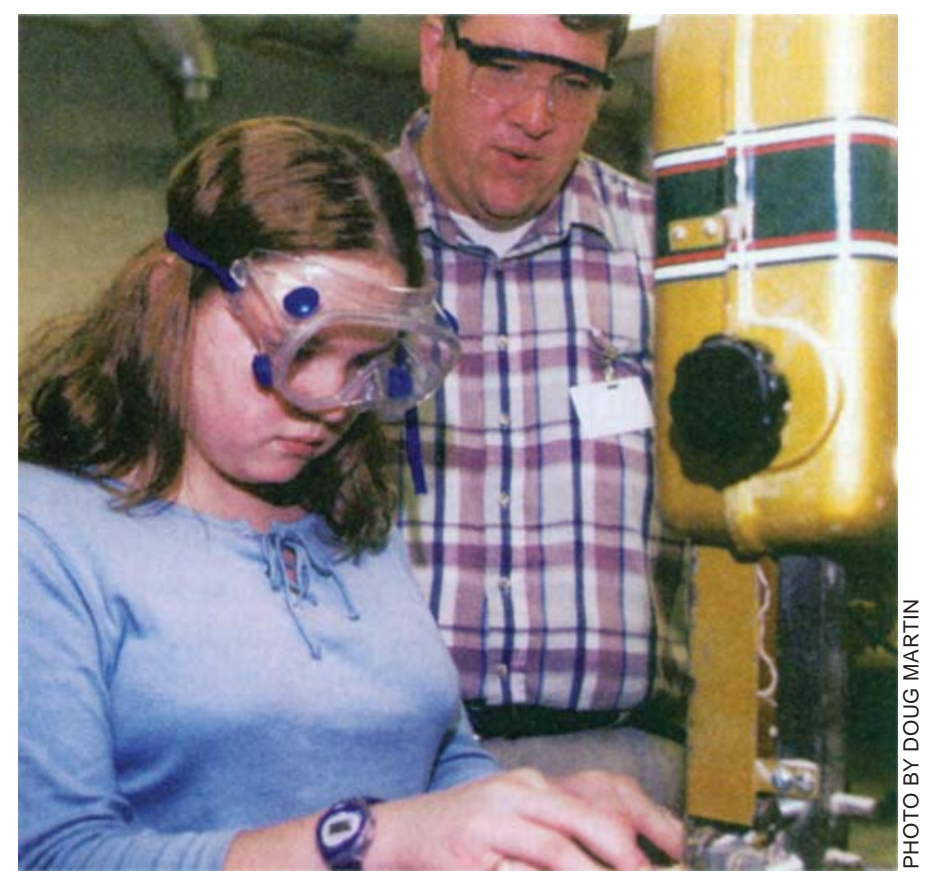

Breaking down stereotypes by respecting differences is key to providing learning tasks that students can invest themselves in.

inquiry through participant observation and interviewing, where dialogue was the fundamental process through which meaning and understanding unfolded. Additionally, we each collected student work documenting responses to learning and wrote journals in which we noted emerging connections, analyses, and interpretations. Taken together, these research activities at three school sites involving 36 young adolescents provided us with evidence about multiple meanings of schooling for adolescent girls.

In one study, "Competing Regimes of Truth in the Lives of Adolescent Girls," 10 girls in grades 
seven and eight who attended two traditional middle schools reported rarely becoming connected to their learning and were in the process of "fading out" of school (Sefa Dei, Massuca, McIsaac, \& Zine, 1997). The second study, "Belonging to Learning," explored how students actively structure what they encounter in school situations deliberately designed to help students make meaning from learning processes. Based on classroom observations and ongoing interviews with 26 students over a two-year period, students experienced a greater sense of belonging when they engaged in school learning encounters involving creating, making, adapting, changing, and attending to difference.

In comparing participants' narratives we discovered striking similarities and differences across common themes such as painful schooling stories, sensitivity to spectacle and display, lack of connection, lost sense of self, and being positioned by tasks, teachers, and peers. Two students' accounts were especially vivid in bringing to life many of these themes. Alicia and Susan both wrestled with their sense of self at school, constructing identities amid what Kelly (1997) called the "contextual density” of schooling. Their accounts

\section{Students experienced more belonging}

when they engaged in learning

encounters involving creating, making,

\section{adapting, changing, and attending to}

\section{difference.}

vividly illustrate that middle schools are a complex venue within which to develop a sense of self. While both girls are engaged in identity creation at school, the ways that individual difference is addressed has a profound impact. When difference is expected, accepted, and respected, a stronger sense of self emerges (Gupta \& Ferguson ,1997). Alicia's account is a personal excerpt from an interview. Susan's account is a written response accompanying a cultural imagery assignment completed for her humanities class.

Alicia: I had an identity crisis because I just didn't know who I was. It's hard to maintain an identity when the push is to be alike. Everybody wants to be the same. But that's stupid because not everybody thinks the same, not everybody acts the same. I feel like an outsider on the inside, because I see myself as an individual. The other kids are more concerned with how their friends see them, but I value intelligence unlike the other kids here. I guess you just have to figure out who you are as a person and it's hard to do that at school especially when the teachers treat you all alike and all the work is the same. Like I hate the stupid worksheets in Math-if there isn't any thinking involved it doesn't appeal to me. I like it when there isn't only one right answer. The lessons are so boring. I don't feel like I have to soak up the information that I'm getting from her lecturing. When she talks, I cannot listen. It just goes in one ear and out the other. Sometimes she talks so much we don't even have any time to do the work. Everything is from the textbook. I don't even have to be there to learn her lessons.

Susan: My work is called Groups Apart. Why is this? How could groups be apart? Quite easily, I believe. In going together we have made ourselves in other groups instead of a whole. The blue set of triangles is the obvious leader group, perfect, perhaps, but only in their own idea of perfection. The other groups are apart, yellow, pink, and some greens. They might want to be like the blues, but are torn by individuality, or not liking the blue's ways. The blues shun the other colors. They want the other colors to be like them, but the others cannot. The blues will not accept the truth. The blues create a generic for everyone to follow; the children must all be the same. Despite the blue's ways, all the colors still fit together, edging in the same direction, either chaos or wonder. The brilliant citrus colors I chose represent that each of the groups is different in its own way, yet is also the same in some ways. If only people would accept that and not try to change it. I find this repeating many times in our culture. When Englishmen came to Canada, they civilized the natives, taking them to schools and insisting on their superior ways. In Western society now, we go to Africa and do the same thing but in a gentler approach. In our school we repeat this. Why must we be judged on our outer looks, or our brains, or something else? Why can't we just be accepted for who we truly are? Those are questions I cannot answer myself, but can only wonder. Is it because we are afraid and simply cower in a safety we have created for ourselves? 
The accounts of Alicia and Susan reveal how peers, tasks, and teachers affect students' sense of self.

\section{Others/Otherness: The impact of peers upon self}

Ruiz (1998) maintained that the social system that peers create for themselves at school is complex and virtually unknown to the adults in the building. In all school sites we observed hierarchical social groups operating according to what Finders (1997) called the power of the peer dynamic. Students affix labels on themselves and others that determined social acceptability and membership in groups (e.g., Popular, Super Popular, Jocks, Losers, Pathetic Wannabe's). This system has a tremendous impact on how Alicia and Susan see themselves and others. They question these terms of inclusion and exclusion dictated by their peers and, at times, openly contest the meanings assigned to their lives. The difference is that Alicia confides these feelings while Susan openly pursues them in her schoolwork.

Alicia admits a felt sense of difference, saying that she feels like an outsider on the inside. She recognizes that she is "other," yet she refuses to mimic her classmates' actions and appearance in order to become more popular, in contrast to the majority of adolescent girls who rate being popular and well-liked as more important than being competent or independent (American Association of University Women, 1992). Alicia finds it difficult, if not impossible, to assert her individuality within the context of schooling where the myth of sameness abounds. The tensions that she experiences between the desire to be different and the push to be the same lead Alicia to seek a sense of her social self outside of school. She chooses to identify with a peer group whose commonality appears to be indifference to the institution of schooling. Socializing with "street kids," she finds the freedom to be different from the identity imposed by her peers at school where she is known as a "Druggie," although she adamantly rejects this label. She classifies herself as an "Independent" because of her non-participation in the social games of her peers: She is indeed an "outsider on the inside." On the street, however, her sense of self is honored and she feels that she belongs. Contrasting her school peers to her street peers, Alicia comments on how peer relationships affect sense of self:
Last year the peer thing was pretty bad. Nobody liked me, everybody had something against me, and I was so self-conscious. Now, most of my friends don't go to school, they're on the street. They're older, more mature, and I can talk to them. I can trust them and say, "Hey, I have a problem" and they won't spread it around or gossip. They just understand better than the kids at school.

On the other hand, Susan is provided with an opportunity in class to question the role of others and otherness in human relationships. Susan and her classmates spend time examining the notion of culture from a variety of perspectives in a humanities class. There are many class discussions stemming from a novel (Tunes for Bears to Dance To by Robert Cormier, 1992) that elicits much debate over values, beliefs, and moral judgments. Susan and her classmates are expected to identify and address a particular cultural concept that each feels matters. They are to synthesize their thinking on this aspect of culture through representing it in some form. Susan invests herself in the image created. She gives consideration throughout the creative process to colors, lines, shapes, and textures, with a concern for the connections between parts and the overall impact of the visual statement. Susan's comments hold an emotional commitment that intimately connects her with her work. Questioning herself throughout the process, she deliberates and responds accordingly. As Susan thinks about her imagery she confronts her own prejudices, fears, and limitations. She creates both a very personal account of acceptance by peers and notes parallel accounts through history.

Alicia and Susan both acknowledge the difficulty of living within and going against the grain of this peer-created social system. In Susan's class, though, students are given the opportunity to explore these issues. In this classroom, a diversity of responses is expected and respected by the teacher and students as the visual work of all students is displayed, honored, and discussed by the class. It seems the impact of others and otherness is brought to the forefront by a forum that encourages analysis, criticism, and questioning. As the images, representing moments of clarity, are discussed, they blur with curiously unfinished or incomplete thoughts, to create an open endedness in this classroom. 


\section{Discovery/Obliteration: The impact of task upon self}

Greene (1978) described how discovery is taken out of learning in many teaching situations: "The self as participant, as inquirer, as creator of meanings has been obliterated" (p. 12). Alicia and Susan address the re-creation of discovery and its obliteration in their accounts.

Alicia recognizes that the majority of her schoolwork obliterates her self as a participant, as an inquirer and as a creator of meanings and fails to provide opportunities for discovery in learning. All too often, Alicia is on the receiving end of learning experiences within a monolithic curriculum. By virtue of her

\section{"Why must we be judged on our outer} looks, or our brains, or something else?

\section{Why can't we just be accepted for who}

\section{we are?}

grade level, Alicia is assumed to have similar, if not identical, needs to her peers. She is positioned by learning tasks within this kind of curriculum as if she is indistinguishable from her classmates. However, Alicia desires challenges in her learning that would engage her in tasks that involve creating, making, adapting, changing, and building meaning. She insists that she loves learning but is rarely given meaningful tasks. Disconnected from her learning and faced with boring, mind-numbing tasks, such as the "stupid” work sheets in math, Alicia, at times, attempts to make the tasks relevant. For example, when given the opportunity to choose her own writing topic in language arts, Alicia adopts a philosophical approach, writing a collection of essays that represent what she calls her "truths." In her conclusion, Alicia writes about the "unwanted one" who is placed in a black box: "a realm of ignorance. A shield from individuality. An outcast. Banding creativity, controller of feelings, shunning emotion." Clearly, she is personally invested in this writing, but the recreation of discovery became the learner's responsibility in this example.

By contrast, Susan is attracted to the ideas she pursues when she is involved with examining culture from a variety of perspectives. This investment of self leads to deeper involvement and greater understanding. The task itself demands this involve- ment. Susan chooses not to evade this demand by assuming an indifference, but rather, undertakes the task not as a given but as something yet to be achieved. Susan embraces the uncertainties of the task, placing herself in the midst, between self and other, as catalyst and sounding board. The task assumes this fundamental reciprocity between self and other. All expectations of the task support the explorations of this interdependence. Susan has the opportunity to make the task personal, is given time and guidance to be attentive to specific qualities and relations, and is encouraged to let the process of thought itself shape her understanding. The learning task is a means to learn rather than an end in itself. The task is a catalyst for development.

\section{Honoring/Silencing difference: The im- pact of teacher upon self}

As Alicia struggles with her sense of self in the classroom, her teacher is supportive and encouraging.

Alicia often seeks out her teacher to privately discuss her sense of difference. Within the messy reality of the classroom, though, the teacher finds it difficult to create a space that honors difference and re-creates discovery in learning. She, too, is constrained by a school context that assumes all students in a particular grade level require the same learning experiences. Mastery learning of required subject matter takes precedence over considering topics that might be related to important issues in the lives of the young adolescents in the classroom. For both teachers and students, school context constrains discovery.

However, in Susan's classroom, the teacher takes primary responsibility for initiating and sustaining reciprocal interaction between students and subject matter. By positioning students to be receptive to sensory qualities and relations of self and subject matter, the teacher searches for ways to draw students into the depth and complexity of subject matter. Time is necessary in order for students to dwell in the learning encounter long enough to wonder and to question. Thus, the teacher develops a variety of nondirective teaching practices that support nonlinear as well as linear learning. Divergent learning responses are encouraged, allowing students some choice in the way they engage with subject matter. A spirit of inquiry is created in which room for experimentation and invention of meaning is fostered. Imaginative thought, requiring speculation and conjecturing about possibilities, evolves. Such conjecture 
creates a space for students to participate in learning more about others and, in turn, themselves.

\section{Conclusion}

Alicia's account demonstrates how conformity in classrooms is often rewarded and school-aged critical thinkers regarded with suspicion (Epp, 1996). In classes such as these, difference is cause for alarm, not celebration. Susan's account shows how building on personal uniqueness in classrooms creates belongingness to learning. Thus, a learning space may celebrate or silence difference, obliterate or re-create discovery. The consequences matter for identity formation.

School tasks can be used to create a forum where issues of "others" and "otherness" are brought to the forefront. When given the opportunity to address issues that matter through school work, students can freely explore questions such as those raised by Susan: "Why must we be judged on our outer looks, or our brains, or something else? Why can't we just be accepted for who we truly are?” Individuality is welcomed in this classroom context. In Alicia's classroom, the question of "Who am I?" is more difficult to answer because conformity is valued. As Alicia notes, "It's hard to figure out who you are as a person especially at school where the teachers treat you all alike and all the work is the same.”

In addition to providing tasks that allow students to describe and critique their social world, we also believe that school tasks should re-create the discovery in learning that provides opportunities for students to become personally invested. They should be expected to participate, inquire, and create meanings as they engage in tasks that demand their involvement. Within such tasks, a diversity of responses is expected. "I like it when there isn't only one right answer," says Alicia. Expecting, accepting, and respecting difference regarding individual students and their work are worthy ideas for middle school settings. As Carson (1995) phrased it:

If living with difference and living in the difference is the experience of teaching today, it seems wrong to make prescriptions or seek to erase it by regulation. If this is the world of the classroom now, what teachers chiefly need is the time and the support for interpreting curricula in light of these situations, (p. 312)

Honoring differences in individual's opinions, thinking, and experiences allows teachers and students to reconsider and reformulate their beliefs. Educators ought not ignore the potential, power, and responsi- bility implicit in expecting, accepting, and respecting differences in our students.

\section{References}

American Association of University Women. (1992). The AAUW Report: How schools shortchange girls. Report by Wellesley College Center for Research on Women. Washington, DC: American Association of University Women and National Education Association.

Brumberg, J. (1997). The body project: An intimate history of American girls. New York: Vintage Books.

Carson, T. (1995). Hearing the voices of teachers. In G. Taylor \& R. Runte (Eds.), Thinking about teaching (pp. 307-313). Toronto: Harcourt Brace.

Cormier, R. (1992). Tunes for bears to dance to. New York: Delacorte Press.

Currie, D. (1999). Girl talk: Adolescent magazines and their readers. Toronto: University of Toronto Press.

Epp, J. (1996). Schools, complicity, and sources of violence. In J. Epp \& A. Watkinson (Eds.), Systemic violence: How schools hurt children (pp. 1-26). London: The Falmer Press.

Finders, M. (1997). Just girls: Hidden literacies and life in junior high. New York: Teachers College Press.

Greene, M. (1978). Landscapes of learning. New York: Teachers College Press.

Gupta, A., \& Ferguson, J. (1997). Culture, power place: Ethnography at the end of an era. In A. Gupta \& J. Ferguson (Eds.), Culture, power, place: Explorations in critical anthropology (pp. 1-21). London: Duke University Press.

Harper, H. (1997). Disturbing identity and desire:

Adolescent girls and wild words. In S. Todd (Ed.), Learning desire: Perspectives on pedagogy, culture, and the unsaid (pp. 141-161). New York: Routledge.

Kelly, U. (1997). Schooling desire: Literacy, cultural politics, and pedagogy. New York: Routledge.

Ruiz, R. (1998). Indiscipline or violence: The problem of bullying in school. Prospects, 28(4), 587-599.

Sefa Dei, G., Massuca, J., McIsaac, E., \& Zine, J. (1997). Reconstructing "Drop-out”: A critical ethnography of the dynamics of black students' disengagement from school. Toronto: University of Toronto Press.

Lori Olafson is an Assistant Professor in the Department of Curriculum \& Instruction, University of Nevada, Las Vegas. E-mail: lolafson@ccmail.nevada.edu

Margaret Macintyre Latta is an assistant professor in the Center for Curriculum \& Instruction at the University of $\mathrm{Ne}$ braska, Lincoln. E-mail: mlattaz@unl.edu 